\title{
EFFECTS OF SENSORY INTEGRATION THERAPY ON SELECTED FITNESS SKILLS IN AUTISTIC CHILDREN
}

DOI: $10.36740 /$ WLek202008106

\author{
Włodzisław Kuliński ${ }^{1,2}$, Adela Nowicka ${ }^{1}$ \\ ${ }^{1}$ COLLEGIUM MEDICUM, JAN KOCHANOWSKI UNIVERSITY, KIELCE, POLAND \\ 2DEPARTMENT OF REHABILITATION, MILITARY INSTITUTE OF MEDICINE, WARSAW, POLAND
}

\begin{abstract}
Introduction: Autism is a pervasive developmental disorder characterised by abnormal development in the first two years of life and impairment with respect to the following three areas: social interactions, communication, and behaviour. The disorder is more common in males than females.

The aim: The study was conducted to assess the effects of sensory integration therapy on selected fitness skills in autistic children.

Material and methods: The study assessed a group of 20 children ( 15 boys and 5 girls) aged 3 to 10 years. All children were diagnosed with autism and underwent 2-year therapy. The children showed impaired sensory modulation with abnormal stimulus reception and processing in the tactile, auditory, vestibular (balance), olfactory, and gustatory sensory systems. The study assessed fitness skills and their correlations with sensory integration therapy used in the children. The assessment used the Sensorimotor Development Questionnaire developed by Zbigniew Przyrowski and selected tests from "Obserwacja Kliniczna" as well as history-taking conducted with the parents. The following aspects were analysed: muscle tone, static balance, dynamic balance, jumping on two legs, jumping on one leg, catching and throwing a ball, and self-care activities, such as putting on shoes. Results: Sensory integration therapy contributed to an improvement in motor, sensory, cognitive, emotional, communication, and social development in the study patients. Conclusion: The use of sensory integration effectively supports sensory processes in autistic children.
\end{abstract}

KEY WORDS: autism, treatment, sensory integration

Wiad Lek. 2020;73(8):1620-1625

\section{INTRODUCTION}

Autism is seen as a developmental disorder, probably determined by biological causes, and manifesting itself in various aspects of a child's functioning [1-6].

Eric Fombonne [7] reviewed 43 population-based studies from different countries and found a prevalence rate of classic autism ranging from $0.7 / 10,000$ to $72.6 / 10,000$, with the disorder being 3 to 4 times more common in males than in females.

Autism is a pervasive developmental disorder whose onset occurs in early childhood, usually in the first two years of life. Its symptoms may vary in degrees and severity and affect the basic aspects of functioning, mainly the following three areas: social interactions, communication, and behaviour. Autistic children often receive, process, and experience sensory stimuli (visual, auditory, tactile, olfactory, and gustatory stimuli) differently. Autistic children ignore certain sounds and over-react to other sounds. They avoid visual stimuli and have very limited eye contact. Sensory integration problems are common, manifesting themselves mostly as various types of auditory, tactile, visual, gustatory, or olfactory hypersensitivity or hyposensitivity. An estimated $40 \%$ of autistic children have some form of sensory sensitivity abnormalities [2-15]. Sensory modulation disorders are the most common disorders in autistic children; they can be divided into two main groups, namely hyperactivity and hypoactivity.
Hyperactive children show a high level of stimulation, are often irritable, loud, and overactive. Hypoactive autistic children show a low level of stimulation, are passive and withdrawn, do not respond to attempts at communication, instructions, and situations around them. Sensory integration disorders make autistic children unable to appropriately process the stimuli received by their nervous system.

\section{THE PRINCIPLES OF SENSORY INTEGRATION THERAPY}

Dr A. J. Ayres, who was a psychologist, occupational therapist, and faculty member at the University of California, is considered to be the author of the sensory integration method.

Sensory integration is a neurological process that organises sensations from the body and the environment so that they can be used to perform intentional actions. Senses provide us with information about the physical condition of our body and the environment. The role of the brain is to locate, sort, and organise the stimuli. When sensations flow in a well-organised and integrated manner, the brain is able to use them to form perceptions, behaviours, and to learn $[16,17,19-22]$.

A. J. Ayres based the concept of sensory integration on the development of sequencing and described it in four stages. Stage 1 includes foetal development and infancy; 
Stage 2 refers to the first year of life, when the most important processes consist in combining vestibular and tactile stimuli with proprioception as well as the development of perception of one's own body. Stage 3 starts after the first year of life of the child and ends at the age of three years; in this period, the child integrates vestibular, tactile, and proprioceptive stimuli with visual and tactile stimuli as well as develops visual and auditory perception and object manipulation abilities (eye-hand coordination). Stage 4 encompasses kindergarten and early school education and is associated with the development of interhemispheric communication and hemispheric specialisation.

Diagnosing sensory integration processes in an autistic child is a difficult task that requires the therapist to observe the child's activity very closely.

\section{SENSORY INTEGRATION THERAPY: SELECTED EXERCISES}

Every autistic child has their own individual sensory profile, with abnormalities whose extent and severity may vary. The sensory integration method is a type of treatment used to work with autistic children. The therapy is adjusted to the needs and mental and physical abilities of each patient. Sensory integration therapy used in autistic children includes the integration of basic postural responses and stimulation of the development of balance reflexes, praxis, spatial orientation, and lateralisation of superficial and deep sensation (Fig. 1). Exercises are selected to improve fine and gross motor skills, concentration, and self-awareness; they become a way to play and learn (Fig. 2).

The following types of equipment are used for the therapy: various types of swings, hammocks, platforms, balance beams, sensory balls, rolling pins, skateboards, spinning plates, helicopters etc. During the therapeutic sessions, children perform appropriately selected sensorimotor exercises not to learn specific exercises, but to improve the function of their sensory systems.

\section{THE AIM AND RESEARCH METHODS}

The study was conducted to assess the effects of sensory integration therapy on selected fitness skills in autistic children. 1. Did study patients show improvements in their emotional, social, cognitive, motor, sensory, and communication development during 2-year sensory integration therapy?

2. Are there correlations between the severity of autism and improvements in fitness skills in children?

3. Are there correlations between age and improvements in fitness skills in children?

Mean values and standard deviation $(\overline{\mathrm{x}} \pm \mathrm{SD})$ were calculated to compare changes in cognitive, emotional, social, and motor development after sensory integration therapy. The significance of the data was tested with Student's t-test for independent samples. The same calculations were performed to analyse the separate areas of psychomotor development and to verify the efficacy of each study method. The significance level was set at $\mathrm{p}<0.05$.
The results are presented in tables and figures. The data was assessed with Student's t-test for independent samples. A chi-square test was also used to explore correlations between two variables. The study evaluated the effects of sensory integration therapy on fitness skills in children.

The study used a modified version of the survey questionnaire developed by Zbigniew Przyrowski [18]. The questions were designed to make it easy for parents to answer whether and how sensory integration therapy influenced selected fitness skills in their children. The study was conducted between 2017 and 2019. The study group consisted of 20 children ( 15 boys and 5 girls) diagnosed with early infantile autism, aged 3 to 10 years. The children underwent sensory integration therapy at the Psychological and Pedagogical Counselling Centre in Staszów and its branch in Połaniec as part of early development support in young children.

\section{MATERIAL AND RESULTS}

The study enrolled 15 boys and 5 girls (Tab. I). The largest age group consisted of children aged 6 years (25\%); the age of 3 years was reported in $20 \%$ of study patients, 8 and 9 years in $15 \%$ each, 7 and 10 years in $10 \%$ each, and $5 \%$ of study patients were aged 4 years (Tab. II ).

In the study group, 25\% of children had severe autism, $40 \%$ were diagnosed with moderate autism, and $35 \%$ had mild autism (Tab. III).

At the time of the study, $5 \%$ of study patients had been undergoing therapy for a month, 15\% for 6 months, and $80 \%$ for more than 2 years (Tab. IV)

Study patients underwent therapy twice a week (30\%), once a week (55\%), or every two weeks (15\%) (Tab. V).

The duration of a single therapeutic session was $60 \mathrm{~min}$ utes $(60 \%)$ or 45 minutes $(40 \%)$ (Tab VI).

In the study group, some children calmed down and focused (10\%), most were happy to perform the activities $(60 \%)$, some were distracted and unable to focus $(25 \%)$, and some participated in the sessions with reluctance (5\%) (Tab VII). Sensory integration therapy had a low (15\%), moderate (60\%), or high (25\%) impact on improvements in balance (Tab. VIII). Sensory integration therapy had a low (20\%), moderate (45\%), or high (35\%) impact on improvements in motor planning (Tab. IX) Sensory integration therapy had a low (20\%), moderate (35\%), or high (45\%) impact on improvements in eye-hand coordination (Tab. X). Sensory integration therapy had a low (10\%), moderate (40\%), or high (50\%) impact on improvements in fine motor skills and lateralisation. (Tab. XI)

In the study group, after sensory integration therapy $10 \%$ of children seemed weaker than other children of the same age, $5 \%$ seemed to be stronger than other children, $10 \%$ had a normal posture and normal grip strength, and $75 \%$ were much better at controlling their body posture (Tab. XII). .

All children (100\%) showed improvements with respect to the motor and sensory parameters. Social aspects were improved in $95 \%$ of study patients, emotional and cognitive aspects in $90 \%$ of cases, and communication in $85 \%$ of study patients. 


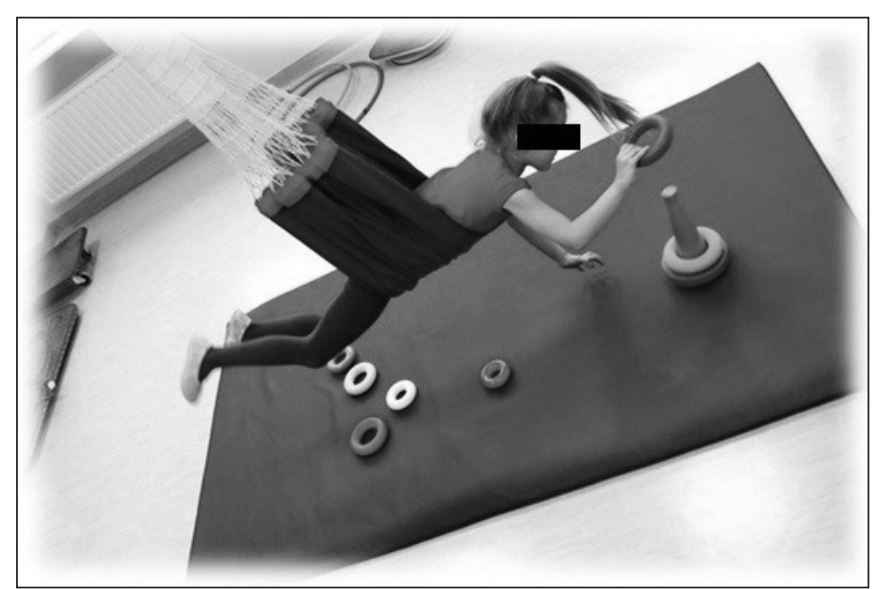

Fig. 1. Stimulation of the vestibular system in a hammock, combined with putting rings on a cone

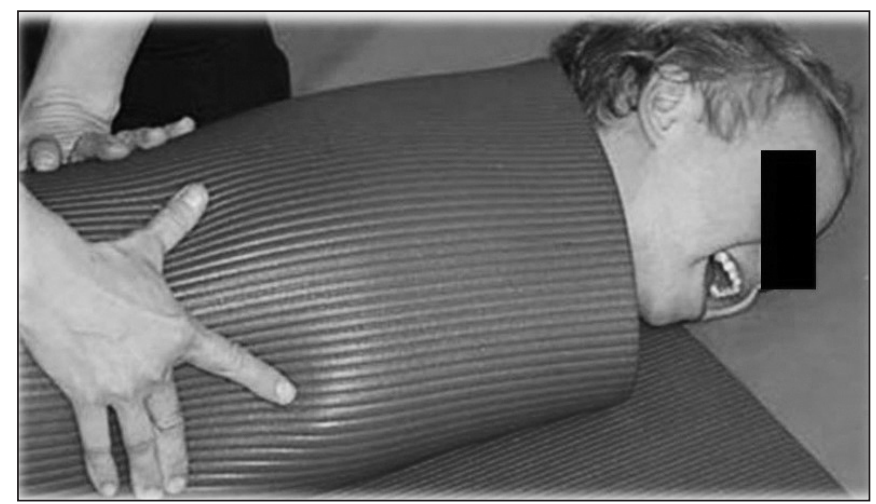

Fig. 2. Stimulating the proprioceptive system by wrapping a child in a sleeping mat

The study evaluated the effects of sensory integration therapy on fitness skills in children; a chi-square test for independence was used (Tab. XIII).

Based on the test ( $p=0.3025)$, no significant difference was found between the values obtained before and after therapy with respect to the ability to stand on one leg (Tab. XIV)

Based on the test $(p<0.0001)$, a significant difference was found between the values obtained before and after therapy with respect throwing and catching a ball; the therapy significantly increased the number of children able to perform this activity (Tab. XV).

Based on the test $(\mathrm{p}<0.0001)$, a significant difference was found between the values obtained before and after therapy with respect to jumping on two legs; the therapy significantly increased the number of children able to perform this activity (Tab. XVI

Based on the test ( $\mathrm{p}=0.3474)$, no significant difference was found between the values obtained before and after therapy with respect putting on shoes.

The study assessed the impact of the severity of autism on improvements in fitness skills; a chi-square test for independence was used (Tab. XVII)..

Based on the test $(p=0.4522)$, no significant correlation was found between improvements in fitness skills and the severity of autism. (Tab. XVIII).
Table I. Gender of study patients

\begin{tabular}{ccc}
\hline Gender of study patients & Number & [\%] \\
\hline Boy & 15 & $75 \%$ \\
\hline Girl & 5 & $25 \%$ \\
\hline
\end{tabular}

Table II. Age of study patients

\begin{tabular}{ccc}
\hline Age of study patients & Number & [\%] \\
\hline 3 years & 4 & $20 \%$ \\
\hline 4 years & 1 & $5 \%$ \\
\hline 6 years & 5 & $25 \%$ \\
\hline 7 years & 2 & $10 \%$ \\
\hline 8 years & 3 & $15 \%$ \\
\hline 9 years & 3 & $15 \%$ \\
\hline 10 years & 2 & $10 \%$ \\
\hline
\end{tabular}

Table III. Degree of autism

\begin{tabular}{ccc}
\hline Degree & Number & [\%] \\
\hline Severe & 5 & $25 \%$ \\
\hline Moderate & 8 & $40 \%$ \\
\hline Mild & 7 & $35 \%$ \\
\hline
\end{tabular}

Table IV. Duration of therapy

\begin{tabular}{ccc}
\hline Duration of therapy & Number & {$[\%]$} \\
\hline A month & 1 & $5 \%$ \\
\hline Six months & 3 & $15 \%$ \\
\hline More than 2 years & 16 & $80 \%$ \\
\hline
\end{tabular}

Table V. Session frequency

\begin{tabular}{ccc}
\hline Session frequency & Number & [\%] \\
\hline Twice a week & 6 & $30 \%$ \\
\hline Once a week & 11 & $55 \%$ \\
\hline Every two weeks & 3 & $15 \%$ \\
\hline
\end{tabular}

Table VI. Therapeutic session duration

\begin{tabular}{ccc}
\hline Therapeutic session duration & Number & [\%] \\
\hline 45 minutes & 8 & $40 \%$ \\
\hline 60 minutes & 12 & $60 \%$ \\
\hline
\end{tabular}

Table VII. Child's behaviour during therapeutic sessions

\begin{tabular}{ccc}
\hline $\begin{array}{c}\text { Child's behaviour during } \\
\text { therapeutic sessions }\end{array}$ & Number & [\%] \\
\hline Calm and focused & 2 & $10 \%$ \\
\hline Happy to perform the activities & 12 & $60 \%$ \\
\hline Distracted and unable to focus & 5 & $25 \%$ \\
\hline Participates with reluctance & 1 & $5 \%$ \\
\hline
\end{tabular}

Based on the test $(p=0.2835)$, no significant correlation was found between improvements in fitness skills and the severity of autism (Tab. XIX). 
Table VIII. Impact of sensory integration therapy on balance improvements

\begin{tabular}{ccc}
\hline $\begin{array}{c}\text { Impact of sensory integration } \\
\text { therapy on balance }\end{array}$ & Number & [\%] \\
\hline Low & 3 & $15 \%$ \\
\hline Moderate & 12 & $60 \%$ \\
\hline High & 5 & $25 \%$
\end{tabular}

Table IX. Impact of sensory integration therapy on improvements in motor planning

\begin{tabular}{ccc}
\hline $\begin{array}{c}\text { Impact of sensory integration } \\
\text { therapy on motor planning }\end{array}$ & Number & [\%] \\
\hline Low & 4 & $20 \%$ \\
\hline Moderate & 9 & $45 \%$ \\
\hline High & 7 & $35 \%$ \\
\hline
\end{tabular}

Table X. Impact of sensory integration therapy on improvements in eyehand coordination

\begin{tabular}{ccc}
\hline $\begin{array}{c}\text { Impact of sensory integration } \\
\text { therapy on eye-hand } \\
\text { coordination }\end{array}$ & Number & [\%] \\
\hline Low & 4 & $20 \%$ \\
\hline Moderate & 7 & $35 \%$ \\
\hline High & 9 & $45 \%$ \\
\hline
\end{tabular}

Table XI. Impact of sensory integration therapy on improvements in fine motor skills and lateralisation

\begin{tabular}{ccc}
\hline $\begin{array}{c}\text { Impact of therapy on } \\
\text { improvements in fine motor } \\
\text { skills and lateralisation }\end{array}$ & Number & [\%] \\
\hline Low & 2 & $10 \%$ \\
\hline Moderate & 8 & $40 \%$ \\
\hline High & 10 & $50 \%$ \\
\hline
\end{tabular}

Table XII. Impact of sensory integration therapy on improvements in muscle tone

\begin{tabular}{lll}
\hline No. $\begin{array}{c}\text { Impact of sensory } \\
\text { integration therapy } \\
\text { on improvements in } \\
\text { muscle tone }\end{array}$ & Number & [\%] \\
\hline Seems to be weaker & & \\
A $\quad \begin{array}{c}\text { than other children, with } \\
\text { abnormal posture when } \\
\text { sitting, standing }\end{array}$ & 2 & $10 \%$ \\
\hline Seems to be stronger \\
B than other children, with \\
excessive grip strength
\end{tabular}

Table XIII. Improvements in individual aspects after therapy

\begin{tabular}{ccc}
\hline Aspects & Number & [\%] \\
\hline Social & 19 & $95 \%$ \\
\hline Emotional & 18 & $90 \%$ \\
\hline Cognitive & 18 & $90 \%$ \\
\hline Motor & 20 & $100 \%$ \\
\hline Sensory & 20 & $100 \%$ \\
\hline Communication & 17 & $85 \%$
\end{tabular}

Table XIV. Standing on one leg

\begin{tabular}{cccc}
\hline Standing on one leg & Before & After & Total \\
\hline Able & 1 & 3 & 4 \\
\hline$[\%]$ column & $5 \%$ & $15 \%$ & \\
\hline Unable & 19 & 17 & 36 \\
\hline$[\%]$ column & $95 \%$ & $85 \%$ & \\
\hline Total & 20 & 20 & 40 \\
\hline
\end{tabular}

Table XV. Throwing and catching a ball

\begin{tabular}{cccc}
\hline $\begin{array}{c}\text { Throwing and } \\
\text { catching }\end{array}$ & Before & After & Total \\
\hline Able & 0 & 16 & 16 \\
\hline \% column & $0 \%$ & $80 \%$ & \\
\hline Unable & 20 & 4 & 24 \\
\hline \% column & $100 \%$ & $20 \%$ & \\
\hline Total & 20 & 20 & 40 \\
\hline
\end{tabular}

Table XVI. Jumping on two legs

\begin{tabular}{cccc}
\hline Jumping on two legs & Before & After & Total \\
\hline Able & 2 & 14 & 16 \\
\hline$[\%]$ column & $10 \%$ & $70 \%$ & \\
\hline Unable & 18 & 6 & 24 \\
\hline$[\%]$ column & $90 \%$ & $30 \%$ & \\
\hline Total & 20 & 20 & 40 \\
\hline
\end{tabular}

Table XVII. Putting on shoes

\begin{tabular}{cccc}
\hline Putting on shoes & Before & After & Total \\
\hline Able & 15 & 17 & 32 \\
\hline$[\%]$ column & $75 \%$ & $85 \%$ & \\
\hline Unable & 5 & 3 & 8 \\
\hline$[\%]$ column & $25 \%$ & $15 \%$ & \\
\hline Total & 20 & 20 & 40 \\
\hline
\end{tabular}

Based on the test $(\mathrm{p}=0.2096)$, no significant correlation was found between improvements in fitness skills and the severity of autism (Tab. XX)

Based on the test $(\mathrm{p}=0.0275)$, a significant correlation was found between improvements in fitness skills and the severity of autism; the lower the severity of the disorder, the higher the probability of improvements (Tab. XXI). 
Table XVIII. Standing on one leg

\begin{tabular}{cccc}
\hline Autism & No improvement & Improvement & Total \\
\hline Severe & 4 & 1 & 5 \\
\hline [\%] column & $22 \%$ & $50 \%$ & \\
\hline Moderate & 8 & 0 & 8 \\
\hline$[\%]$ column & $44 \%$ & $0 \%$ & \\
\hline Mild & 6 & 1 & 7 \\
\hline$[\%]$ column & $33 \%$ & $50 \%$ & \\
\hline Total & 18 & 2 & 20 \\
\hline
\end{tabular}

Table XIX. Jumping on one leg

\begin{tabular}{cccc}
\hline Autism & No improvement & Improvement & Total \\
\hline Severe & 4 & 1 & 5 \\
\hline [\%] column & $24 \%$ & $33 \%$ & \\
\hline Moderate & 8 & 0 & 8 \\
\hline$[\%]$ column & $47 \%$ & $0 \%$ & \\
\hline Mild & 5 & 2 & 7 \\
\hline$[\%]$ column & $29 \%$ & $67 \%$ & \\
\hline Total & 17 & 3 & 20 \\
\hline
\end{tabular}

Based on the test ( $\mathrm{p}=0.2096)$, no significant correlation was found between improvements in fitness skills and the severity of autism (Tab. XXII)

Student's t-test for independent samples was used. The test did not show any significant correlation between age and improvements in fitness skills in children as a result of sensory integration therapy (Tab. XXIII).

\section{DISCUSSION}

Recently, autism has been one of the most commonly diagnosed developmental disorders in children. The first manifestations of autism can be seen very early, in the first two years of a child's life. People with autism spectrum disorders are different in terms of behaviour, thought processes, and everyday functioning. They withdraw into their own world, which is often impossible to understand for others. They detect sensory stimuli from the environment differently from non-autistic people, and their nervous system is unable to appropriately process the stimuli. Consequently, their behaviour may be difficult to understand: they may shake their hands, jump in place,
Table XX. Throwing and catching a ball

\begin{tabular}{cccc}
\hline Autism & No improvement & Improvement & Total \\
\hline Severe & 2 & 3 & 5 \\
\hline$[\%]$ column & $50 \%$ & $19 \%$ & \\
\hline Moderate & 2 & 6 & 8 \\
\hline$[\%]$ column & $50 \%$ & $38 \%$ & \\
\hline Mild & 0 & 7 & 7 \\
\hline$[\%]$ column & $0 \%$ & $44 \%$ & \\
\hline Total & 4 & 16 & 20 \\
\hline
\end{tabular}

Table XXI. Jumping on two legs

\begin{tabular}{cccc}
\hline Autism & No improvement & Improvement & Total \\
\hline Severe & 3 & 2 & 5 \\
\hline$[\%]$ column & $38 \%$ & $17 \%$ & \\
\hline Moderate & 5 & 3 & 8 \\
\hline$[\%]$ column & $63 \%$ & $25 \%$ & \\
\hline Mild & 0 & 7 & 7 \\
\hline$[\%]$ column & $0 \%$ & $58 \%$ & \\
\hline Total & 8 & 12 & 20 \\
\hline
\end{tabular}

Table XXII. Putting on shoes

\begin{tabular}{cccc}
\hline Autism & No improvement & Improvement & Total \\
\hline Severe & 3 & 2 & 5 \\
\hline [\%] column & $19 \%$ & $50 \%$ & \\
\hline Moderate & 6 & 2 & 8 \\
\hline$[\%]$ column & $38 \%$ & $50 \%$ & \\
\hline Mild & 7 & 0 & 7 \\
\hline$[\%]$ column & $44 \%$ & $0 \%$ & \\
\hline Total & 16 & 4 & 20 \\
\hline
\end{tabular}

walk on their toes, scream, screech, hit their own head with their hands etc. Their speech may be incomprehensible, with an incorrect accent. Autistic people often have difficulty establishing normal relations with others. Early detection of the disorder and management supporting the psychomotor development of autistic children are very important. Moreover, it is important to adjust the therapy to each patient. An assessment of the effects of sensory integration therapy in the study patients showed that the motor performance of these children improved significantly after treatment.

Table XXIII. The impact of age on improvements in fitness skills.

\begin{tabular}{|c|c|c|c|c|c|c|}
\hline \multirow{2}{*}{$\begin{array}{l}\text { Impact of age on fitness } \\
\text { improvements }\end{array}$} & \multicolumn{2}{|c|}{ No improvement } & \multicolumn{2}{|c|}{ Improvement } & \multirow{2}{*}{$\mathbf{T}$} & \multirow{2}{*}{$\mathbf{P}$} \\
\hline & Mean & SD & Mean & SD & & \\
\hline Standing on one leg & 6.3 & 2.4 & 8.5 & 0.7 & -1.2426 & 0.2299 \\
\hline Jumping on one leg & 6.4 & 2.5 & 7.3 & 1.5 & -0.6099 & 0.5495 \\
\hline Throwing and catching a ball & 6.3 & 3.8 & 6.6 & 2.1 & -0.2758 & 0.7859 \\
\hline Jumping on two legs & 7.0 & 2.9 & 6.3 & 2.0 & 0.6828 & 0.5034 \\
\hline Putting on shoes & 6.1 & 2.3 & 8.5 & 1.7 & -1.9727 & 0.0641 \\
\hline
\end{tabular}


The study enrolled 20 children aged 3 to 10 years., including 15 boys and 5 girls, with mild to moderate autism, and assessed their fitness skills before and after sensory integration therapy. The following aspects were analysed: standing on one leg, jumping on two legs, eye-hand coordination improvement, throwing and catching a ball, tying up shoelaces, improvements in fine motors skills and lateralisation, and improvements in muscle tone.

The present study showed that after two years of sensory integration therapy, autistic children had improved social, emotional, cognitive, sensory, and communication functioning. The children were very happy to participate in the sessions, which were conducted using play techniques.

An assessment of the results of sensory integration therapy in study patients revealed significant differences in such fitness skills as jumping on two legs and catching and throwing a ball. However, there were no significant differencesin standing on one leg or jumping on one leg. This could be explained by the low baseline values of motor skills in the study group, or the severity of autism; $40 \%$ of the children had moderate autism and $25 \%$ were diagnosed with severe autism. Their motor developmental deficits (of the vestibular and proprioceptive systems) may be so severe that they do not allow for achieving higher values.

\section{CONCLUSIONS}

1. Sensory integration therapy contributes to an improvement in motor, sensory, cognitive, emotional, communication, and social development in the study patients.

2. Sensory integration therapy improves such fitness skills as throwing a ball, jumping on two legs, and catching a ball.

3. Motor function improvements in autistic children depend on early initiation of therapy.

\section{REFERENCES}

1. GyawaliS, Patra BN. Autism spectrum disorder: Trends in research exploring etiopatogenesis. Psychiatry Clin Neurosci. 2019, 73 (8): 466-475.

2. Altun H, Kurutas EB, Sahin N et al. The levels of vitamin D, vitamin D receptor, homocysteine and complex $B$ vitamin in children with autism spectrum disorders. Clin Psychopharmacol Neurosci. 2018;30;16(4):383-390.

3. Fluegge K. Humoral immunity and autism spectrum disorders. Immunol Lett. 2017;05(185):90-92.

4. Siu MT, Weksberg R. Epigenetics of Autism Spectrum Disorder. Adv Exp Med Biol. 2017;978:63-09.

5. Peretti S, Mariano M, Mazzocchetti C et al. Diet: the keystone of autism spectrum disorder? Nutr Neurosci. 2019;22 (12):825-839.

6. Lyons V, Fitzgerald M. Asperger (1906-1980) and Kanner (1894-1981), the two pioneers of autism. J Autism Dev Disord 2007;37:2022-2023.

7. Fombonne E. Epidemiology of pervasive developmental disorders. Pediatr Res 2009;65(6):591-598.

8. Welch C, Cameron D, Fitch M, Polatajko H. Living in autistic bodies: bloggers discuss movement control and arousal regulation. Disabil Rehabil. 2020;25:1-9.

9. Pesko MJ, Burbige EM, Sannar EM et al. The use of n-acetylcysteine supplementation to decrease irritability in four youths with autism spectrum disorders. J Pediatr Pharmacol Ther 2020;25(2):149-154.

10. Saurman V, Margolis KG, Luna RA. Autism spectrum disorder as a braingut_microbiome axis disorder. Dig Dis Sci. 2020;65(3):818-828.
11. McFayden T, Jarrett MA, White SW et al. Sluggish cognitive tempo in autism spectrum disorder, ADHD, and their comorbidity: implications for impairment. J Clin Child Adolesc Psychol. 2020;6:1-8.

12. Banire B, Khowaja k, Mansoor B et al. Reality-based technologies for children with autism spectrum disorder: a recommendation for food intake intervention. Adv Neurobiol. 2020;24:679-693.

13. Trzmiel T, Purandare B, Michalak $M$ et al. Equine assisted activities and therapies in children with autism spectrum disorder: a systematic review and meta-analysis. Complement Ther Med. 2019;42:104-113.

14. Srinivasan SM, Cavagnino DT, Bhat AN. Effects of equine therapy on individuals with autism spectrum disorder: a systematic review. Rev J Autism Dev Disord. 2018;5(2):156-175.

15. McDaniel Peters BC, WoodW. Autism and equine-assisted interventions: a systematic mapping review. J Autism Dev Disord. 2017;47(10):3220-3242.

16. Borgi M, Loliva D, Cerino S et al. Effectiveness of a standardized equineassisted therapy program for children with autism spectrum disorder. J Autism Dev Disord. 2016 ;46(1):1-9.

17. Charles JM, Carpenter LA, Jenner W, Nicholas JS. Recent advances in autism spectrum disorders. Int J Psychiatry Med. 2008;38:133-144.

18. Przyrowski Z. Integracja sensoryczna, teoria, diagnoza, terapia. Warszawa: Wydawnictwo EMPIS, 2019.

19. Xy W, Yao J, Liu W. Intervention effect of sensory integration training on the behaviors and quality of life of children with autism. Psychiatr Danub. 2019;31(3):340-346.

20. Schoen SA, Lane SJ, Mailloux Z et al. A systematicic review of ayres sensory integration interventionfor children with autism. Autism Res 2019;12(1):6-19.

21. Allen S, Casey J. Developmental coordination disorders and sensory processing and integration: incidence, associations and co-morbidities. Br J Occup Ther. 2017;80(9):549-557.

22. Ashburner JK, Rodger SA, Ziviani JM, Hinder EA. Comment on: An intervention for sensory difficulties in children with autism: a randomized trial'by Schaaf et al. (2013). J Autism Dev Disord. 2014;44(6):1486-8.

23. Pfeiffer BA, Koenig K, Kinnealey $M$ et al. Effectiveness of sensory integration interventions in children with autism spectrum disorders; a pilot study. Am J Occup Ther. 2011;65(1):76-85.

\section{ORCID and contributionship}

Włodzisław Kuliński - 0000-0002-6419-4030 A,B,D,E,F

Adela Nowicka - ${ }^{B, C, D, E}$

\section{Conflict of interest}

Authors declare no conflict of interest

\section{CORRESPONDING AUTHOR Włodzisław Kuliński}

st. K Miarki 11B, 01-496 Warszawa, Poland

e-mail:wkulinski52@hotmail.com

Received: 14.03 .2020

Accepted: 02.07.2020

A - Work concept and design, B - Data collection and analysis, C - Responsibility for statistical analysis,

D-Writing the article, $\mathbf{E}$-Critical review, $\mathbf{F}$-Final approval of the article 